Do the Best Companies to Work for Provide Better Customer Satisfaction?

Daniel H. Simon

Cornell University

Department of Applied Economics and Management

354 Warren Hall

Ithaca, NY 14853

Phone: (607) 255-1626

Email: dhs29@ cornell.edu

Fax: (607) 255-9984

and

Jed DeVaro

Cornell University

Department of Labor Economics

268 Ives Hall

Ithaca, NY 14853

Phone: (607) 255-8407

Email: devaro@cornell.edu

Fax: (607) 255-4496 


\section{Do the Best Companies to Work for Provide Better Customer Satisfaction?}

\section{ABSTRACT}

Using data from both the American Customer Satisfaction Index (ACSI) and Fortune Magazine's lists of Best

Companies, we examine the relationship between making the "Best 100" list and customer satisfaction. Based on a subset of the Best 100 in each year from 1994 to 2002, we find strong evidence that firms on the list earn higher customer satisfaction ratings than firms not on the list. This result is stronger for firms in the service sector than for those in the manufacturing sector. Our analysis also suggests that the increase in customer satisfaction resulting from Best Company status yields about a 1.6 percent increase in return on assets. 
A handful of papers have examined the effect on firm performance of being named a "Best Company to Work For," with the results generally revealing a positive relationship. Firms that are seen as Best Companies have better employee attitudes and relations (Fulmer et al., 2003), which yield advantages in attracting, motivating, and retaining employees (Ostroff \& Bowen, 2000). Therefore, one might expect that these firms would provide higher quality products and better service to their customers. To consider this possibility, we examine the impact of being named to Fortune Magazine's list of "100 Best Companies to Work For" on a firm's overall customer satisfaction, as measured by the American Customer Satisfaction Index (ACSI). Our results show that firms benefit from Best Company status, though this effect varies with the type of industry and is larger in services than in manufacturing. We also quantify a positive effect of Best Company status on a measure of three-year return on assets.

This study offers four main contributions. First, it adds to the small but growing literature on the performance effects of being a "Best Company." This is an important issue for strategic management, given that firms allocate substantial resources to being named Best Companies and because of the significant amount of attention that it receives in the popular press. It is important to assess whether being a Best Company has real effects on firm performance.

Second, we focus on customer satisfaction rather than financial measures of firm performance. Customer satisfaction is more directly related to workplace environment than is the firm's financial performance. By examining the impact of being a Best Company on a firm's customer satisfaction, we shorten the causal linkage, illuminating the mechanism through which being a Best Company may lead to better financial performance. Moreover, understanding the determinants of customer satisfaction is critical because "satisfied customers may be the most consequential of all economic assets; indeed, they may be proxies for all other economic assets combined" (Fornell, 2001: 120).

Firm-level customer satisfaction is a fundamental indicator of the firm's current and future performance (Anderson $e t$ al., 1997), providing both behavioral and economic benefits to the firm. In particular, customer satisfaction has been found to increase customer loyalty (Anderson \& Sullivan, 1993; Bearden \& Teel, 1983; Bolton \& Drew, 1991; Boulding et al., 1993; Fornell, 1992). Through its effect on loyalty, customer satisfaction has been linked to increased revenues (Fornell, 1992; Rust et al., 1995), more inelastic demand (Anderson, 1996), and reduced transaction costs (Fornell, 1992), including costs for attracting new customers, and other costs associated with poor quality, defects and complaints (Anderson et al., 1997). Reflecting these benefits, customer satisfaction has been found to have a strong, positive effect on a firm's profitability (Anderson, et al., 1994; Aaker \& Jacobson, 1994; Capon et al., 1990).

Third, we examine the conditions under which the relationship between customer satisfaction and Best Company status may be stronger or weaker. Specifically, we examine whether and how the benefits to Best Company status vary by industry type. In doing so, the study helps to define a boundary condition on the relationship between Best Company status and firm performance. Moreover, assessing the impact of industry on the effect of interest helps us to better understand the mechanisms through which being a Best Company impacts firm performance. 
Fourth, this is the first study of Best Companies that uses panel data. Unlike other studies which only compare the performance of firms that make the list with the performance of firms that do not make the list, we also compare the same firm's performance when it makes the list versus when it does not make the list. In doing so, we can control for unobserved firm characteristics that might influence both employee attitudes and relations, and a firm's customer satisfaction. In addition, while other studies of Best Companies have used data for only one year of Best Companies (the first year Fortune Magazine published the list), we examine the effect of Best Company status over a nine-year period. This enhances the credibility of our results. Because, if the true performance effect of Best Company status is not stable over time, then a finding (from a single-year study of the type that is common in the literature on the performance effects of Best Company status) of a positive effect in a given year might be the consequence of selecting a "good year". In contrast, we are measuring an average effect of Best Company status over a nine-year period, so that a finding of a positive effect, should one emerge, is more meaningful.

\section{Prior Research and Hypotheses}

By offering good compensation, a pleasant working environment, opportunities for advancement, and other benefits, firms on the Best Companies list may instill more positive attitudes in their employees. In doing so, these firms may increase the quality of their workforces as well as the intensity of employee effort, resulting in improved product and service quality.

Employee attitudes can impact a firm's customer satisfaction by affecting the quality of employees attracted to the firm and the effort they exert (Ostroff \& Bowen, 2000; Fulmer et al., 2003). Some management scholars suggest that if employees feel good about their jobs, the positive sense of well-being will cause them to work more effectively (Schneider \& Bowen, 1992). In economics, the notion of efficiency wages suggests that firms may pay above-market wages or offer other benefits as a way to increase employees' incentives to work hard; employees will work harder when they have more to lose. In Best Companies, employees will perceive that they have more to lose by performing poorly, as firing poses a greater risk. As a result, they should work harder to protect their jobs. This increased effort should increase customer satisfaction by reducing defect rates and/or improving customer service.

Best Company status can also affect a firm's customer satisfaction level through its effect on employee quality. Positive employee attitudes can improve a firm's ability to attract new employees because current employees can vouch for the quality of the work environment. Similarly, Best Company status provides a signal to prospective employees about the quality of the work environment (Hannon \& Milkovich, 1996). Moreover, employees who are happy with their working conditions are less likely to quit (Trevor, 2001). As employees accumulate experience with the firm they become more proficient at their jobs. Employees that have worked together longer are likely to provide better quality and service, because providing high levels of customer satisfaction usually requires a cooperative effort (Hauser et al., 1994).

Beyond their influence on employee effort and quality, positive employee attitudes may be observable by customers and may enhance customers' buying experience in retail settings where employees interact directly with customers (George, 
1991; Liao \& Chuang, 2004). Therefore, Best Companies' positive employee attitudes may directly affect customer satisfaction in certain contexts.

Several studies have sought to link Best Company status with firm performance. Hannon and Milkovich (1996) test whether being named a "best company to work for" in the business press has a significant effect on the firm's stock price. They use six different lists of best companies ranging from "Best for Black Engineers" to "Best for Working Mothers," and also including a partial list of the companies cited in Levering and Moskowitz's (1993) The 100 Best Companies to Workfor in America. Of the six lists, only those firms named "Best Companies for Working Mothers" enjoyed positive unexpected returns around their announcement.

Focusing on the firms in Fortune Magazine's 1998 list of the 100 Best Companies, Lau and May (1998) find that these companies enjoyed greater sales growth and higher ROA than firms in the S\&P 100 (that are not on the list). Filbeck and Preece (2003) find a statistically significant increase in a firm's stock price following the announcement that it had been named to the 1998 Fortune list. Moreover, they find some evidence that the Best Companies enjoyed higher returns than a matched sample of firms that did not make the list. Similarly, Fulmer et al., (2003) find that the 100 Best Companies enjoyed higher stock prices and better financial performance than a matched sample of firms.

In a related research stream, a growing number of studies finds that the use of bundles of complementary human resource management (HRM) practices has a positive effect on firm performance. These bundles of HRM practices generally include sophisticated recruiting procedures and selection processes, appraisal systems linked to incentive plans, and organizational structures that encourage cooperation among employees (Huselid, 1995). Ichniowski et al. (1997) examine the effect of innovative HRM systems on the quality and productivity of output of finishing lines in steel producing firms. They find that finishing lines that adopted innovative HRM systems increased quality (and productivity) substantially. Also focusing on the steel industry, Arthur (1994) finds that mini-mills using HRM systems that emphasize employee commitment are more efficient than mini-mills using HRM systems that emphasize cost. In the automobile industry, MacDuffie (1995) finds that the use of HRM policies emphasizing commitment and motivation increases manufacturing productivity, with this effect moderated by the firm's production process. Using a multi-industry sample, Huselid (1995) finds that firms using High Performance Work Practices enjoy higher productivity, lower turnover, and better financial performance than firms that do not use these practices.

Building on these findings, and the causal mechanisms described above linking employee attitudes, quality, and motivation to customer satisfaction, we hypothesize:

\section{H1: Best Company status has a positive effect on customer satisfaction.}

While all firms should benefit from being named a Best Company, it would appear that some firms might benefit more than others. In particular, we expect service firms to benefit more than manufacturing firms. Service quality is more dependent on the activities of employees than is product quality, which depends on the quality of material inputs used to make the product 
as well as the effort of employees. As argued in Anderson, Fornell, and Rust (1997), standardization tends to be more important than customization in determining customer satisfaction with manufactured goods. In contrast, in service industries customization of the output is more important and there is a greater role of personnel for determining quality. As noted in Anderson, Fornell, and Rust (1997), "Many services are personnel intensive, customized to suit heterogeneous needs and preferences, jointly produced by both producer and customer(s), and intangible (Lovelock, Magi and Julander 1996, Shostack 1977, Gronroos 1990). These characteristics imply customization quality will be more important in determining customer satisfaction ...". As a result of the greater customization and customer involvement, worker-customer interactions are more common and intensive in services than in manufacturing. Due to this higher degree of customer interaction in services, positive worker attitudes and behaviors that arise from Best Company status will be more visible to customers and more likely to impact customer satisfaction in service settings than in manufacturing. The fact that the positive attitudes of workers can enhance the buying experience of customers with whom they directly interact in retail settings has been noted in George (1991) and Liao \& Chuang (2004).

In addition, employees have a proportionately greater influence on prices of services, because in manufacturing firms costs of material inputs influence prices as well. This greater reliance on labor, as an input, makes service firms more susceptible to having their level of customer satisfaction eroded by changes in employee attitudes, effort, and quality. Service firms that are unable to attract and/or retain talented employees will suffer greater declines in customer satisfaction than will manufacturing firms. Moreover, unhappy and unmotivated employees who exert little effort will have a more negative effect on service quality than on the quality of goods. Given this higher level of customer interaction outside of manufacturing settings, and because employee attitudes, quality, and effort influence service quality and prices more than product quality and prices, we hypothesize that:

H2: Best Company status has a more positive effect on customer satisfaction in service industries than in manufacturing industries.

\section{DATA AND METHODS}

\section{Sample 1: The American Customer Satisfaction Index}

The American Customer Satisfaction Index (ACSI) is a quarterly survey designed to measure customer satisfaction with the quality of consumer goods and services (a large set of "brands") available in the United States (ACSI, 2001). These brands are broadly representative of the U.S. economy serving household consumers (ACSI, 1999), spanning more than forty industries in seven economic sectors, and comprising about $40 \%$ of U.S. GDP (ACSI, 2001). Each quarter, about 250 telephone interviews are conducted with randomly selected current customers for one quarter of the brands in the Index. Since each brand's customers are surveyed in the same quarter every year (with a few exceptions), each brand has one customer satisfaction rating per year, and roughly one quarter of the observations fall in each quarter of the year. After excluding government agencies and 
observations with missing data, the sample includes 1399 observations, comprising 195 firms in 29 different industries, spanning a nine-year period from 1994-2002. These years provide an interesting period to study because of the growing popularity of lists of Best Companies and the substantial variation in labor-market conditions.

\section{Sample 2: Fortune's List of Best Companies to Work For}

Each year since 1998, Fortune Magazine has published a list of the "100 Best Companies to Work For in America." This list is compiled by Levering and Moskowitz, through the Great Place to Work Institute, extending the work they began with books of the same name published in 1980, 1993, and 2000. For a detailed description of the selection process used for the 1998 list, see Fulmer et al., 2003 and Filbreck \& Preece, 2003. Our focus here is mainly on the evolution of the list since its initial release on January 12, 1998.

For the initial 1998 list, Levering and Moskowitz invited 238 firms to submit information for consideration. To be considered, a company must have been in existence for at least seven years (ten years until 2002) and must have at least 1000 employees (until 2003 the threshold was 500 employees). Moreover, a company cannot be considered when it is involved in a merger or acquisition which adds $25 \%$ or more to its total US labor force.

Each candidate company must randomly select 250 employees (up from 225 in 1998) who will receive a 55-item survey called the Great Place to Work Trust Index. The survey, developed by the Great Place to Work Institute of San Francisco, is designed to measure a range of employee attitudes including trust in management, pride in work/company, fairness, respect, and camaraderie (more survey details and sample survey items are available at www.greatplacetowork.com). The selected employees return the surveys directly to the data processor, ensuring that the employees' responses are confidential and anonymous to the company (Fulmer et al., 2003). In addition to the survey employees are also invited to provide additional comments.

Along with the information provided by employees, the candidate companies complete a comprehensive 29-page questionnaire developed by Hewitt Associates. Companies are also invited to submit additional supporting information, including employee benefits booklets, videos and newsletters. Companies are then rated on a 175-point scale. The employee survey is worth 100 points, and the evaluation of handwritten comments is worth 20 points, so that together the employeeprovided information is worth more than two thirds of the total points. The remaining fifty-five points are allocated to the company survey and an evaluation of other materials submitted by the company.

While Fortune does not provide information on employee response rates, the magazine did disclose that 40,713 employees completed the survey for the 2003 list. With 269 participating companies providing surveys to 250 employees each, this yields a total of 67,250 employee surveys, and a response rate of $61 \%$. This is similar to the $58 \%$ response rate reported by Fulmer et al., (2003) for 1998. In addition, beyond simply responding to the survey items, each year about $40 \%$ of employees include handwritten comments as well. 
As discussed above, one of the primary explanations for why firms on the Fortune list would have higher customer satisfaction is that their employees have more positive attitudes. Because Fortune does not release the results of the employee surveys, it is difficult to verify this. However, Fulmer et al. (2003) provide strong evidence that, at least in 1998, the firms on the Fortune list indeed do have more positive attitudes. They obtained data for six attitude items that were collected for all applicant firms, but which were not used to select the 100 Best, finding that these six items demonstrate "substantial internal consistency reliability" (Fulmer et al., 2003: 976). Moreover, the correlation between these six items and membership on the list (among firms that applied) is 0.67 (Fulmer et al., 2003). Finally, and perhaps most importantly, using data from two other surveys along with the employee survey described above, Fulmer et al. (2003) compare employee responses to an item that asks about the employee's intention to remain with the current employer. They find that employees at the 100 Best Companies are substantially more likely than employees at other firms to respond that they intended to remain with their current employer. This evidence suggests that employee attitudes are more positive at the 100 Best.

\section{Analysis Sample}

We merge the ACSI sample (which contains information on customer satisfaction) and the Fortune sample (which contains information on Best Company status) to produce our analysis sample. Not surprisingly, only a modest number of "Best 100" firms in a given year appear in the ACSI, and these tend to be among the largest firms on the Fortune list (which makes them more comparable to the ACSI firms than would be a random sample of the Best 100, since as a group the ACSI firms are larger than the Fortune firms). Thus, our empirical analysis is based on two types of firms: those that make the Best 100 list and also appear in the ACSI, and those that do not make the Best 100 list but appear in the ACSI. This requires us to neglect a large fraction of Best 100 firms due to lack of matching information on customer satisfaction from the ACSI. Table 1 displays a list of the Best 100 companies that appear in our ACSI sample, by year.

\section{---INSERT TABLE 1 ABOUT HERE---}

The fact that we can consider only a subsample of Best 100 firms, as opposed to the entire population of Best 100 firms, is one limitation of our analysis. It cannot be established with certainty that our results apply to all "Best 100" firms, since we consider only a rather small subset of them, so one should be cautious in making inferences regarding the Best Companies that are excluded from our sample. Nonetheless, the fact that we are able to consider only a modest fraction of Best 100 firms need not pose serious problems. While an analysis based on all Best 100 firms would obviously be ideal, an analysis based on only a subsample of Best 100 firms is informative if two conditions hold. First, the subsample must at least be large enough to generate believable results. Second, the subsample must be selected in such a way that it does not introduce a source of bias in the estimated effects of interest.

Our analysis satisfies the first condition; while only a modest 6 to 7 percent of the analysis sample attains Best Company status according to our definition, in our opinion this is large enough to generate meaningful results, particularly given 
that the sample size is large overall. As for the second condition, while a pure random sample of Best 100 companies would be sufficient to satisfy this condition, that is not necessary. All that is required is that the factors determining which of the Best 100 companies enter our sample are uncorrelated with customer satisfaction. There is no a priori reason to expect that the Best 100 companies selected into our analysis sample are systematically different (along the dimension of customer satisfaction) from those that do not enter our analysis sample. Table 2 presents some indirect evidence in support of this. We compare the means of the following variables for Best 100 firms that are included in our sample and for those that are excluded: a firm's ranking from 1 to 100 on the Best 100 list, a measure of annual percentage job growth, number of new jobs created during the previous two years, number of applicants, annual turnover rate, and training (hours per year). To save space we present these comparisons for only the first and last year for which we have data from Fortune Magazine (the 1998 and 2003 lists of Best Companies).

$$
\text { ---INSERT TABLE } 2 \text { ABOUT HERE--- }
$$

Table 2 confirms a point we have made earlier, namely that the Fortune firms that enter our sample tend to be the larger Fortune firms. The two variables "new jobs" and "applicants", both of which relate directly to firm size, are larger for the included than for the excluded Best Companies, and these differences in means are statistically significant in 1997 (not in 2002). However, for the other variables the differences in means between the included and excluded Best 100 firms are statistically insignificant. The difference between the two groups in dimensions related to firm size does not pose problems for our analysis, since we control for firm size in most models. Furthermore, the fact that the variables other than firm size do not differ on average between the two groups is consistent with our claim that the two groups are unlikely to differ systematically along the dimension of customer satisfaction. Based on these considerations, we believe the second condition is very likely to be satisfied in our analysis (i.e. factors influencing the selection of Best Companies into our sample is uncorrelated with customer satisfaction) and that the results are interesting.

\section{Empirical Model}

Other studies of Best Companies have focused on a single year (specifically 1998, the first year that Fortune Magazine published the list) and have compared the performance of the 100 Best to a matched sample of firms, without controlling for unobserved heterogeneity at the level of the individual firms. These analyses attribute any difference in performance between firms on the list and those not on the list to the effect of being a Best Company. While the matched sample approach provides a reasonable test of the effect of being a Best Company given a single year of data, our study takes a different approach that offers some advantages over the single-year approach.

Unlike the earlier studies, we consider several years of Best Company lists rather than just one, including (in some of our analyses) the list published in The 100 Best Companies to Work for in America (Levering \& Moskowitz, 1993). In addition, because it seems likely that there may be other factors causing differences in customer satisfaction between firms on the Best 100 list and firms not on the list, we include a set of control variables, described below. Furthermore, we consider two types of 
analyses. First, like the earlier studies, we estimate cross-sectional models in which we compare the customer satisfaction of firms on the list with the customer satisfaction of firms in the same industry that are not on the list (i.e. we include industry fixed effects but not firm fixed effects). However, because there may be unobserved firm-level factors that help to explain the difference in customer satisfaction between the Best Companies and the other firms, we also consider a model with firm fixed effects. In this model, we compare the difference in performance when a firm is on the list versus when the same firm is not on the list. The firm fixed effects hold constant unobservable firm characteristics that might influence both making the Fortune list and customer satisfaction. Finally, because the error terms for brands owned by the same parent company may be correlated, we estimate standard errors clustered on the parent company.

\section{Dependent Variable: Customer Satisfaction}

ACSI uses a multiple indicator approach to measure overall customer satisfaction. A brand's overall customer satisfaction is measured as a composite of three survey measures: (1) an overall rating of satisfaction, (2) the degree to which performance falls short of or exceeds expectations, and (3) a rating of performance relative to the customers' ideal good or service in the category (Fornell, Johnson, Anderson, Cha, \& Bryant, 1996). Each of these three items is measured on a 10-point scale. The customer-level responses are then aggregated to the brand level, and an overall customer satisfaction rating (on a 0100 scale) for each brand is computed by combining the aforementioned three items. Each brand's customer satisfaction rating represents "its customers' overall evaluation of total purchase and consumption experience, both actual and anticipated" (Fornell et al., 1996: 7).

\section{Independent Variable}

Best Company. Using the annual Fortune Magazine lists, we consider two different definitions of Best Companies. Because the Fortune list is published in January or February, in both cases we assume that the list corresponds to information from the prior year. That is, if a firm appears in Fortune's 1999 list of Best Companies, then we interpret this as an indication of employee attitudes and HRM policies at the firm during 1998.

Although it is not our preferred measure of best company status, we begin the analysis with a "Best Company" dummy variable equaling one if a firm makes the Fortune list in a given year, and zero otherwise. For example, since Southwest Airlines appears in the Fortune Magazine list published in 1999, Southwest would be considered a Best Company in 1998. While this definition provides an exact match with the record from the Fortune list, a big disadvantage is that it significantly curtails our sample size by allowing us to use only data from the years beginning with 1997, given that Fortune Magazine did not begin releasing lists until 1998. We therefore consider a second measure of Best Company status, in which we also make use of the list of Best Companies reported in Levering and Moskowitz' (1993) book. In this broader definition, a firm is considered a Best Company if it either made the Fortune list during the current year or if it both made the list in the previous year and again in the 
subsequent year. For example, consider a firm that makes the list in 1998, but does not make it in 1999, and then makes the list again in 2000. This firm would be considered a Best Company in all three years under this definition.

The advantage of this broader definition is that it allows us to use three more years of data, since any firm that makes the list in 1997 and is also included in Levering and Moskowitz' (1993) book is considered a Best Company in 1994-1996. While this second definition of Best Company status is less stringent than the first, it seems reasonable given the stability of employee attitudes and HRM practices over time. Fulmer et al. (2003) show there is substantial stability in the employee attitudes of companies applying for the Fortune list. Similarly, it seems unlikely that firms change their HRM practices greatly from year to year, so that a firm that is considered a good place to work for in years $t-1$ and $t+1$ is very likely a good place to work for in year $t$ as well.

An important point is that if, as a result of using our second definition of Best Company status, we miscode some firms as Best Companies which in fact are not, this is a conservative error which biases the coefficient on the Best Company variable toward zero, reducing the likelihood of observing a statistically significant effect. Furthermore, another potential source of miscoding of Best Company status arises because only about one thousand firms are either nominated or recruited for the list each year, making it likely that many firms in the sample that are not on the list for a particular year were not considered for inclusion. Therefore, some of the firms in the sample that did not apply for the list may offer the same or even greater benefits than some of the firms on the list. For example, Southwest Airlines, which had been ranked among the top five best companies in each year from 1998-2001, removed itself from consideration for the list in 2002, and again in 2003, (Fortune, 2002). However, it seems unlikely that many firms would do this, because firms with satisfied employees and employee-friendly policies have an incentive to apply for the Fortune list as a means of signaling their high-quality work environment (Hannon \& Milkovitch, 1996). Nonetheless, if firms not on the Best 100 list offer equally employee-friendly environments then this would make it unlikely that a statistically significant relationship would be identified. Thus, an important point to bear in mind is that the consequence of these sources of coding errors is that our estimate of the relationship between Best Company status and customer satisfaction is likely to underestimate the true relationship.

Although our dummy indicators of Best Company status are somewhat crude measures of the firm's underlying attitudes and HRM policies, they offer two important benefits. First, the measures are consistent with prior research that emphasizes the importance of bundles of HRM policies, as opposed to individual HRM practices (Huselid, 1995; Ichniowski et al., 1997). Second, because the dummy variable specification allows the inclusion of firms that do not apply to be on the Fortune list, it precludes the potential selection bias that arises when studying the effects of HRM practices using only those firms that respond to a survey (Huselid, 1995).

\section{Control Variables}


Other studies have compared the performance of the 100 Best to a matched sample of firms without controlling for labor market conditions or for unobserved firm-level heterogeneity. Our analysis controls for the following industry and firmlevel factors.

Manufacturing versus Service Brands. To distinguish between manufacturing and service brands, we define a manufacturing dummy variable that takes a value of one for all brands that are in manufacturing industries, and zero otherwise. We use the industry classifications that are used by the developers of the ACSI, defining every non-manufacturing industry as "services." In some cases, the same firm appears more than once in the ACSI sample, with different brands in different industries. In these cases, the value of the manufacturing dummy depends on the industry in which each brand is listed. Table 3 displays information on the composition of our "manufacturing" and "services" groups by detailed industry category.

$$
\text { ---INSERT TABLE } 3 \text { ABOUT HERE--- }
$$

It is important to note that, because our regression models include industry fixed effects as described below, we cannot estimate a coefficient on the manufacturing dummy as this would create a situation of perfect multi-collinearity. However, we can include in our models the interaction of the manufacturing and Best Company dummy variables. This allows us to test Hypothesis 2 , which predicts that service firms benefit more than manufacturing firms from being named a Best Company. A negative and statistically significant interaction term would be consistent with this hypothesis.

Labor market conditions. To measure labor market opportunities, we use industry-specific, quarterly unemployment rates. When unemployment is high, labor market opportunities are low, and vice versa. We match these data with the quarter in which the firm's customer satisfaction is measured. Because nearly all of the companies included in the ACSI survey are competing throughout the U.S., using national measures of unemployment is appropriate. Furthermore, because the customer satisfaction data pertain to a particular product or service, using unemployment data at the industry level provides greater precision than using the economy's overall rate of unemployment. To our knowledge, this is the first study in the literature on the performance effects of Best Company status to control for labor market conditions.

Multiple Brands Dummy. We include a dummy variable for firms that have more than one brand in the ACSI.

Firm Size. We control for firm size with two variables: the firm's total number of employees and the firm's total assets, as reported in Compustat. These variables are missing for the few private and foreign-owned firms in the ACSI. The firm size control is important in that it predicts Best Company status (since larger Fortune firms are more likely to enter our sample than smaller ones) and potentially predicts customer satisfaction.

Past Firm Profitability. We control for the firm's past profitability using the average return on assets (ROA) during the previous three-year period. To compute annual ROA, we divide net income (before depreciation) by total assets (from Compustat data). This variable is missing for the few private and foreign-owned firms in the ACSI. 
Quarter Fixed Effects. In addition to the above control variables, all models also include fixed effects for each quarter of the year included in the sample (e.g. there is a dummy variable for the first quarter of 1994, the second quarter of 1994, etc.). The quarter dummy variables control for any annual or seasonal differences in customer satisfaction.

Industry Fixed Effects. All models also include industry fixed effects. These industry-specific dummy variables control for unobserved differences across industries in customer satisfaction ratings and frequency of Best Companies. The inclusion of industry fixed effects allows us to control more completely for industry variation in customer satisfaction than we could by including instead a dummy for manufacturing. As mentioned earlier, a manufacturing dummy is superfluous in the presence of industry fixed effects and would create a situation of exact multi-collinearity.

Firm Fixed Effects. Finally, in some of the models we also include firm fixed effects. Including these fixed effects yields a within-firm analysis, in which we compare the customer satisfaction of brands before and after the parent firm is named a Best Company. The firm fixed effects control for unobserved differences across firms that may affect both customer satisfaction and the likelihood of being named a Best Company. Ours is the first study in this literature to control for unobserved firm-level heterogeneity in measuring the relationship between Best Company status and firm performance; this method accounts for the fact that unobserved characteristics of firms that determine customer satisfaction are likely correlated with those that determine Best Company status.

\section{RESULTS}

Table 4 presents descriptive statistics. Brands in the sample attain the Best Company list about six percent of the time (seven percent using our broader definition of "Best Company"), while the average customer satisfaction rating is about 76 (on a 100-point scale). Because the first Fortune list of Best Companies was not published until January, 1998, the more restrictive measure of Best Company takes missing values for the years 1994-1996. Reflecting the tight labor markets of the late 1990s, the average unemployment rate for the sample is a modest $4.7 \%$ even though the average unemployment rate in 1994-1996 exceeded $5 \%$. The firms in the sample are relatively large, with an average of 113,000 employees. Table 5 compares the Best Companies with the other firms in the ACSI sample. As can be seen, the Best Companies have fewer assets but more employees and higher ROA. However, they compete in similar labor markets and are quite similar in manufacturing status, and membership in multibrand companies. Therefore, these Best Companies appear quite comparable with the rest of the ACSI.

\section{---INSERT TABLES 4 \& 5 ABOUT HERE---}

Tables 6 and 7 present the results for the tests of Hypothesis 1. In Table 6, we exclude firm fixed effects. The results in Table 6 provide support for H1, as they show that firms on the 100 Best Companies list enjoy higher customer satisfaction ratings than firms not on the list. In Column 1, we include the Best Company variable and the unemployment rate. In Column 2 , we control for firm size, and in Column 3 we also control for the firm's past profitability. In all three models, the effect of Best Company is statistically significant, raising customer satisfaction by 2.3 to 3 points. 


\section{---INSERT TABLE 6 ABOUT HERE---}

In Columns 4-6, we use the broader definition of Best Company, allowing us to include all years, beginning with 1994. In all three models, Best Company is positive and statistically significant, providing additional support for H1. The magnitudes are even larger than in Columns 1-3; firms on the 100 Best Companies list earn customer satisfaction ratings ranging from 2.8 to 3.2 points higher than those for similar firms in the same industry that did not make the list. Since H1 is a directional hypothesis, we use a one-tailed test as our criterion for statistical significance when testing the result for Best Company status in Columns 16. As indicated in Table 6, in every specification the result of interest achieves statistical significance at the one percent level on a one-tailed test, though it is worth noting that the results are strong enough that significance at the one percent level would be achieved in all cases even using two-tailed tests.

While we control for firm size, profitability, and the labor market conditions they face, the firms in our sample may possess other characteristics that are correlated both with making the Best Company list and earning high customer satisfaction ratings. For example, firms with better management may be more likely to both be a Best Company and to earn high customer satisfaction ratings. Similarly, newer firms (or older firms) may be more likely to enjoy high customer satisfaction ratings and to make the Best Company list. In all of these cases, the unobserved variables could create a spurious positive correlation between Best Company status and customer satisfaction. In order to limit the possibility of spurious correlations, we re-estimate the above regressions including firm fixed effects to control for unobserved firm characteristics. Table 7 reports the results.

\section{---INSERT TABLE 7 ABOUT HERE---}

In Table 7, the more restrictive measure of Best Company has no statistically significant effect on customer satisfaction, while the more broadly-defined measure has a positive and statistically significant effect on customer satisfaction. Again, our criterion for statistical significance is a one-tailed test since H1 is a directional hypothesis. However, while the effect using our preferred broader definition of Best Company status is positive and statistically significant, the magnitude of the effect is smaller than it was in the analyses of Table 6 that excluded firm fixed effects. In the presence of firm fixed effects, attaining the Best Company list is associated with only a 0.9-point increase in customer satisfaction. This substantial reduction in magnitudes in Columns 4-6 of Table 7 compared with the corresponding columns from Table 6 suggests that while the Best Companies do earn higher customer satisfaction ratings, some part of this relationship is driven by unobserved firm characteristics that are correlated with both customer satisfaction and being named to the list. Nonetheless, the fixed effects results using the broader definition also suggest that some part of the relationship may be causal. That is, even after controlling for unobserved firm characteristics, firms earn higher customer satisfaction ratings when they make the list than when they do not. While previous studies have focused on outcomes other than customer satisfaction (e.g. financial performance), our results suggest that the positive performance effects of Best Company status found in those studies are potentially overestimated to a significant degree. 
While the sample sizes are significantly larger using our preferred broader measure of Best Company status, it is somewhat surprising that evidence of a positive effect of Best Company status is so much stronger using the broader definition than using the narrower definition. Further analysis yields a possible explanation for this. Note that the broader definition of Best Company status allows us to use the additional years of data from 1994 to 1996. A t-test reveals that the unemployment rate during these years is significantly higher than during the rest of the sample period (mean of 5.2 versus a mean of $4.5, p=0.000$ ). In unreported analysis we find some evidence that the positive effect of Best Company status is amplified when unemployment is high. In turn, since the broader definition allows us to include additional years with relatively high unemployment, the Best Company effect may be greater than in the sample that omits those years.

Hypothesis 2 examines whether the benefits of being a Best Company vary with the firm's activities. Specifically, H2 posits that service brands benefit more from being a Best Company than do manufacturing brands, because service brands are more dependent on the efforts of their employees. To test this hypothesis, we include in the model a variable that interacts the Best Company dummy variable with the Manufacturing dummy variable. To save space, we report results for only the broader definition of Best Company, our preferred measure, though the results using the more restrictive definition are quite similar. Results are displayed in Table 8. Firm fixed effects are excluded in Columns 1 to 3 and included in Columns 4 to 6.

$$
\text { ---INSERT TABLE } 8 \text { ABOUT HERE--- }
$$

The results of the models excluding firm fixed effects provide strong support for $\mathrm{H} 2$. In all three models, the results show that while Best Company has a positive and statistically significant main effect, the interaction term is negative and statistically significant. The results suggest that within the same service industry, Best Company status is associated with an increase in customer satisfaction ranging from 4.2 to 4.6 points, whereas in manufacturing industries this increase is less than one point. In the fixed effects models, the pattern of results is similar although the magnitudes are smaller and only the main effects achieve statistical significance. Nonetheless, since the interactions in Columns 4-6 are at least of the correct sign, the collective evidence from Table 8 provides at least weak support for H2. And again, the sizeable reduction in magnitudes resulting from the inclusion of firm fixed effects highlights the importance of accounting for unobserved firm-level heterogeneity in this literature. Our results suggest that the estimates of the performance effect of Best Company status in previous work, although focusing on dependent variables other than customer satisfaction, are likely overstated to a potentially significant degree.

\section{Effect of Best Company Status and Customer Satisfaction on Return on Assets}

Our results indicate that Best Companies earn higher customer satisfaction ratings. As discussed earlier, this provides a possible mechanism to explain the positive relationship between Best Company status and financial performance that has been found in the previous literature. To examine whether this is the case, we investigate the effect of customer satisfaction on profitability, using as a dependent variable the firm's average ROA for the three-year period following the current year. Because 
we measure ROA at the firm level, we report results only for those firms that have only one brand in the ACSI. Table 9 reports the results of these analyses.

\section{---INSERT TABLE 9 ABOUT HERE---}

In the first column, we estimate a regression using the three-year average ROA as a dependent variable, including customer satisfaction as an independent variable as well as the full set of control variables (excluding firm fixed effects). The results show that customer satisfaction has a positive and statistically significant effect on ROA. When customer satisfaction increases by one point, the firm's ROA increases by about 0.3 percentage points per year (more precisely, 0.26 ) over the next three years. In the second column, we add firm fixed effects to the specification. In this model, customer satisfaction again has a statistically significant effect on ROA; a one-point increase in customer satisfaction increases average ROA by about 0.2 percentage points (more precisely, 0.17). Given how heavily controlled these models are, the results provide strong evidence that customer satisfaction positively affects profitability. This suggests that customer satisfaction is indeed one mechanism by which Best Company status can positively affect a firm's financial performance.

We now use the results from Tables 7 and 9 to examine the impact of Best Company status on profitability through the mechanism of improved customer satisfaction. By multiplying the effect of Best Company on customer satisfaction by the effect of customer satisfaction on ROA, we can get an estimate of the overall effect of Best Company status on profitability through its impact on customer satisfaction. Since Tables 7 and 9 each present multiple specifications, we must choose one specification from each for the purpose of computing our product. We use the estimates from the last column of each table; that is, we use our preferred broader definition of Best Company status and the most conservative (i.e. most heavily controlled) models. The coefficient of Best Company status from Column 6 of Table 7 is 0.929 , and the coefficient of customer satisfaction from Column 2 of Table 9 is 0.0017 (rounded up to 0.002 in the table). Thus, we estimate that by increasing customer satisfaction, Best Companies earn about $0.929 \times 0.17 \approx 0.16$ percentage points higher ROA per year during the following three years. Note that we have multiplied 0.0017 by 100 so as to express the effect of interest in terms of percentage points. With a mean ROA of 15 percent, this is about a one percent increase in profits. To further examine the magnitude of this effect, consider that the mean firm in the sample has total assets worth about $\$ 13$ billion. Increasing ROA by 0.16 percentage points would be worth nearly $\$ 21$ million of additional profits, annually, or more than $\$ 62$ million over three years.

Finally, since one of the main contributions of our approach in this paper is to control for unobserved heterogeneity at the level of individual firms, it is interesting to consider how the preceding calculation would differ using the single-year approach that has been used in the previous literature on the performance effects of Best Company status. Pulling the relevant estimates from our specifications that omit firm fixed effects (i.e. Column 6 of Table 6 and Column 1 of Table 9), we estimate that by increasing customer satisfaction, Best Companies earn about $2.767 \times 0.26 \approx 0.72$ percentage points higher ROA per year during the following three years (again, we multiply 0.0026 , which was rounded up to 0.003 in Table 9, by 100 so as to express 
the effect of interest in terms of percentage points). Increasing ROA by this amount would be worth over $\$ 93$ million of additional profits, annually, or more than $\$ 280$ million over three years. Thus, employing the single-year approach that has been used in the literature would lead one to over-estimate by more than 350 percent the amount by which Best Company status is expected to increase ROA over three years.

\section{DISCUSSION}

A handful of studies using data from a single year have found a positive correlation between being named a Best Company to work for and firm performance. Using panel data spanning nine years, this study seeks to further examine this relationship by focusing on whether the Best Companies to work for provide higher levels of customer satisfaction (H1). Our finding of a positive effect provides one likely explanation for the positive relationship between Best Company status and financial performance. In addition, this study considers a boundary condition on the positive effect of Best Company status, by examining the influence of the firm's activities (service vs. manufacturing industries) on the relationship between Best Company status and customer satisfaction $(\mathrm{H} 2)$.

The results support the hypothesis that Best Companies earn higher customer satisfaction ratings. This suggests that when employees are happier and more motivated, they provide higher quality products and offer customers better service. Moreover, these results demonstrate that customer satisfaction is an area where strategic human resource management can affect firm performance. The results also demonstrate that the relationship between being a Best Company and high customer satisfaction ratings is contingent on the firm's activities. We find that the benefit of attaining Best Company status is higher in service industries than in manufacturing, highlighting the relatively greater role that employees play in service firms relative to manufacturing firms. As a result, service companies have greater incentives to invest resources in becoming a Best Company, as they can expect a greater payoff from attracting higher quality workers and inducing greater effort from them.

Finally, the results suggest that some of the positive relationship between being a Best Company and firm performance may be due to unobserved firm characteristics creating spurious correlations. While models with and without firm fixed effects provide evidence that being a Best Company improves customer satisfaction, the effect sizes in the models without firm fixed effects are about three times as large as those in the models with firm fixed effects. The smaller effect sizes in the fixed-effects models suggest that there are unobserved firm characteristics that are correlated with Best Company status and customer satisfaction, creating an upward bias in the estimated relationship between the two. We demonstrated a calculation in which the effect of Best Company status on three-year ROA would be over-estimated by nearly 400 percent using the single-year methods that have appeared in this literature to date.

\section{Limitations}

First, like all studies examining the link between HRM systems and firm performance, there is a concern that the HRM system is endogenous. That is, firm performance may drive the firm's decision to become a Best Company, rather than the 
opposite. To try to address this endogeneity, we control for profitability during the previous three years. The effect of Best Company status does not change substantially when we do so, suggesting that this is not a major concern.

Second, while this study focuses on being named to Fortune's list of Best Companies, this masks the policies, attitudes and behaviors underlying Best Company status. That is, we cannot say which policies or bundles of policies are driving the positive effect of being a Best Company. Nonetheless, given the amount of attention that these lists receive in the popular press, and the resources firms devote to being named to these lists, it is important to understand the benefits of being named a Best Company.

Third, while we suggest that being a Best Company can yield benefits in attracting, motivating, and retaining employees, we cannot observe these intermediate steps in the causal chain. We can only infer that it is through these intermediate steps that Best Companies earn higher customer satisfaction ratings. Nonetheless, the results showing a more positive effect for service firms bolster the plausibility of these arguments, as service firms rely more intensively on labor inputs in generating their output than do manufacturing firms (which also rely heavily on materials and equipment).

Fourth, as we have mentioned, it is possible that some companies that could have attained the list chose not to apply for this distinction. This creates a bias in our results, but one that reduces the likelihood that we would find a statistically significant effect of being a Best Company. Therefore, finding the positive effects that we do in spite of this bias actually suggests that the "true effect" of being a Best Company is even greater than what we report.

Finally, as previously noted, only a relatively modest fraction of the 100 Best Companies in any year are included in the ACSI. Therefore, only these Fortune firms are included in the empirical analysis. Thus, it cannot be established with certainty that our results can be generalized to Best 100 firms that do not appear in our sample. However, our use of a subsample of the Best 100 rather than all of them should not pose a problem as long as the determinants of selection of a Best 100 company into our analysis sample are uncorrelated with customer satisfaction, which seems plausible. Furthermore, the Best Companies that are selected into our sample tend to be larger than those that are excluded, which makes them more comparable to the ACSI firms (which are, as a group, larger on average than the Best 100 firms). In any event, systematic differences by firm size do not present problems since we control for firm size in all of our analysis.

\section{Conclusion}

This study contributes to the growing evidence that firms named "Best Companies to work for" enjoy superior performance. In this study, we provide evidence that the 100 Best Companies to Work For provide higher customer satisfaction. This suggests a causal mechanism for how the Best Companies are able to outperform their rivals financially. In addition, the study suggests a boundary condition on the positive effects of being a Best Company. In particular, service firms gain greater benefits (in terms of customer satisfaction) than manufacturing firms from attaining Best Company status. Taken collectively, our results emphasize the key role of the firm's human capital, and the management of this capital, in determining the firm's 
ability to provide quality products and service to customers. For managers, it indicates that investments in employee programs are not only a cost, but also a benefit (Becker \& Gerhart, 1996). Moreover, it suggests that HRM practices can be used not only to improve efficiency but also to improve quality. 


\section{REFERENCES}

Aaker D, Jacobson R. 1994. The financial information content of perceived quality. Journal of Marketing Research, 31: 191-201.

ACSI, 1999, 2001. American Customer Satisfaction Index Report. University of Michigan Business School: Ann Arbor.

Anderson E 1996. Customer satisfaction and price tolerance. Marketing Letters, 7: 265-274.

Anderson, E, Fornell C, Lehmann D. 1994. Customer satisfaction, market share, and profitability: Findings from Sweden. Journal of Marketing, 58: 53-66.

Anderson E, Fornell C, Rust R. 1997. Customer satisfaction, productivity, and profitability: Differences between goods and services. Marketing Science, 16: 129-145.

Anderson E, Sullivan M. 1993. The antecedents and consequences of customer satisfaction for firms. Marketing Science, 12: 125-143.

Bearden W, Teel J. 1983. Selected determinants of consumer satisfaction and complaint reports. Journal of Marketing Research, 20: 21-28.

Becker B, Gerhart B. 1996. The impact of human resource management on organizational performance: progress and prospects. Academy of Management Journal, 39, 779-801.

Bolton R, Drew J. 1991. A multistage model of customers' assessments of service quality and value. Journal of Consumer Research, 17: 375-384.

Boulding W, Kalra A, Staelin R, Zeithaml V. 1993. A dynamic process model of service quality: From expectations to behavioral intentions. Journal of Marketing Research, 30: 7-27.

Capon N, Farley J, Hoeni S. 1990. Determinants of financial performance: a meta-analysis. Management Science, 36: 1143-1159.

Filbreck G, Preece D. 2003. Fortune's 100 best companies to work for in America: Do they work for shareholders? Journal of Business Finance and Accounting, 30: 771-797.

Fornell C. 1992. A national customer satisfaction barometer: The Swedish experience. Journal of Marketing, 56: 6-21.

Fornell C. 2001. The science of satisfaction. Harvard Business Review, 79: 120-121.

Fornell C, Johnson M, Anderson E, Cha J, Bryant B. 1996. The American Customer Satisfaction Index: Nature, purpose, and findings. Journal of Marketing, 60: 7-18.

Fulmer I, Gerhart B, Scott K. 2003. Are the 100 best better? An empirical investigation of the relationship between being "a great place to work" and firm performance. Personnel 
Psychology, 56: 965-993.

George J. 1991. State or trait: Effects of positive mood on prosocial behaviors at work. Journal of Applied Psychology, 76: 299-307.

Hannon J, Milkovich G. 1996. The effect of human resource reputation signals on share prices: An event study. Human Resource Management, 35: 405-424.

Harter J, Schmidt F, Hayes T. 2002. Business-unit-level relationship between employee satisfaction, employee engagement, and business outcomes: a meta-analysis. Journal of Applied Psychology, 87: 268-279.

Hauser J, Simester D, Wernerfelt B. 1994. Customer satisfaction incentives. Marketing Science, 13: 327-350.

Huselid M. 1995. The impact of human resources management practices on turnover, productivity, and corporate financial performance. Academy of Management Journal, 38: 635-672.

Ichniowski C, Shaw K, Prennushi G. 1997. The effects of human resource management practices on productivity: A study of steel finishing lines. American Economic Review, 87: 291-313.

Lau R, May B. 1998. A win-win paradigm for quality of work life and business performance. Human Resource Development Quarterly, 9: 211-226.

Levering R, Moskowitz M. The 100 best companies to work for in America. New York: Doubleday/Currency.

Liao H, Chuang A. 2004. A multilevel investigation of factors influencing employee service performance and customer outcomes. Academy of Management Journal, 47: 41-58.

Ostroff C, Bowen D. 2000. Moving HR to a higher level: HR practices and organizational effectiveness. In K. Klein \& S. Kozlowski, S. (Eds.), Multilevel theory, research, and methods in organizations: 211266. San Francisco: Jossey-Bass.

Rust R, Zahorik A, Keiningham T. 1995. Return on quality (ROQ): Making service quality financially accountable. Journal of Marketing, 59: 58-70.

Schneider B, Bowen B. 1992. The service organization: Human resources management is crucial. Organization Dynamics, 21: 39-53.

Trevor C. 2001. Interactions among actual ease-of-movement determinants and job satisfaction in the prediction of voluntary turnover. Academy of Management Journal, 44: 621-638. 


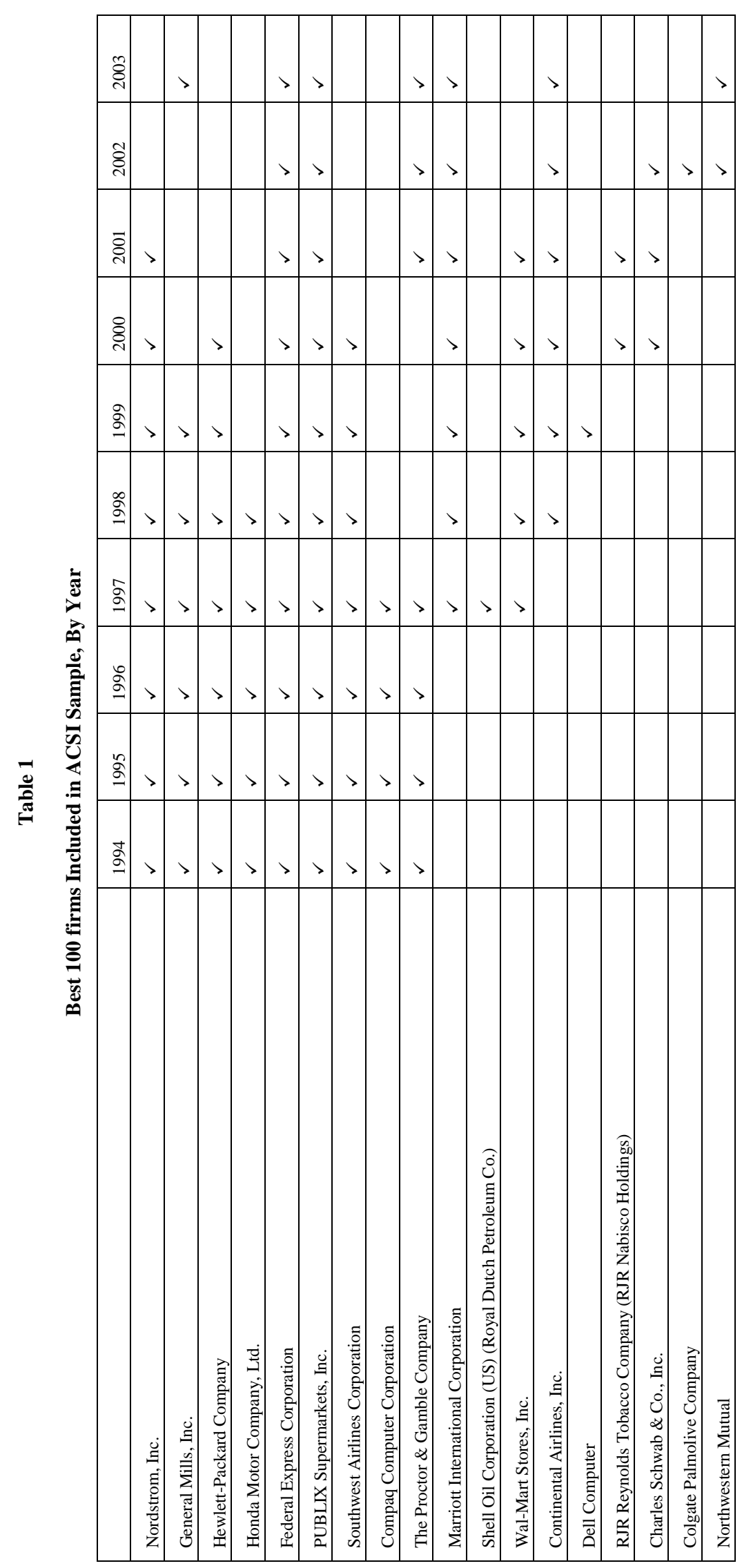

ส 
Table 2

Comparison of Means Between Included and Excluded Best 100 Companies

\begin{tabular}{|l|l|l|l|l|}
\multicolumn{4}{|c}{1998 List } & \multicolumn{2}{c|}{2003 List } \\
\hline & $\begin{array}{l}\text { Included } \\
\text { Best } \\
\text { Companies }\end{array}$ & $\begin{array}{l}\text { Excluded } \\
\text { Best } \\
\text { Companies }\end{array}$ & $\begin{array}{l}\text { Included } \\
\text { Best } \\
\text { Companies }\end{array}$ & $\begin{array}{l}\text { Excluded } \\
\text { Best } \\
\text { Companies }\end{array}$ \\
\hline Rank $(1-100)$ & 46 & 51 & 67 & 49 \\
\hline Job Growth & 0.133 & 0.187 & -0.029 & 0.022 \\
\hline New Jobs & 3447 & $930^{* *}$ & -317 & 124 \\
\hline Applicants & 332,271 & $35,654^{* *}$ & 98,886 & 62,958 \\
\hline Turnover & 0.087 & 0.120 & 0.073 & 0.101 \\
\hline Training (hours per year) & 46.3 & 39.3 & 42.29 & 44.72 \\
\hline
\end{tabular}

** difference in means is statistically significant at one percent level on a two-tailed t-test 
Table 3

Industry Composition of "Manufacturing" and "Services"

Manufacturing Industries

Percent

\begin{tabular}{|c|c|}
\hline Apparel & 7.34 \\
\hline Athletic Shoes & 3.07 \\
\hline Automobiles & 30.03 \\
\hline Beverages - Beer & 4.61 \\
\hline Beverages - Soft drinks & 4.44 \\
\hline Food Processing & 22.01 \\
\hline Household appliances & 5.29 \\
\hline Personal care products & 7.68 \\
\hline Personal computers & 8.19 \\
\hline Pet Foods & 4.78 \\
\hline Tobacco - Cigarettes & 2.56 \\
\hline TOTAL & $100 \%$ \\
\hline
\end{tabular}

Service (or Non-manufacturing) Industries Percent

\begin{tabular}{|l|l|}
\hline Airlines - scheduled & 7.75 \\
\hline Auction/Reverse Auction & 1.11 \\
\hline Banks & 5.29 \\
\hline Brokerage & 0.74 \\
\hline Cable/Satellite TV & 1.23 \\
\hline Department and Discount Stores & 11.93 \\
\hline Gas-service stations & 5.90 \\
\hline Hotels & 6.40 \\
\hline Life Insurance & 3.57 \\
\hline Parcel delivery & 2.21 \\
\hline Personal Property Insurance & 3.32 \\
\hline Restaurants - fast food - pizza - carry out & 8.86 \\
\hline Retail & 1.60 \\
\hline Specialty Retail Stores & 0.98 \\
\hline Supermarkets & 8.12 \\
\hline Telecommunications - local & 4.92 \\
\hline Telecommunications - long & 3.81 \\
\hline Utilities & 22.26 \\
\hline \multicolumn{1}{|c|}{ TOTAL } & $\mathbf{1 0 0 \%}$ \\
\hline
\end{tabular}




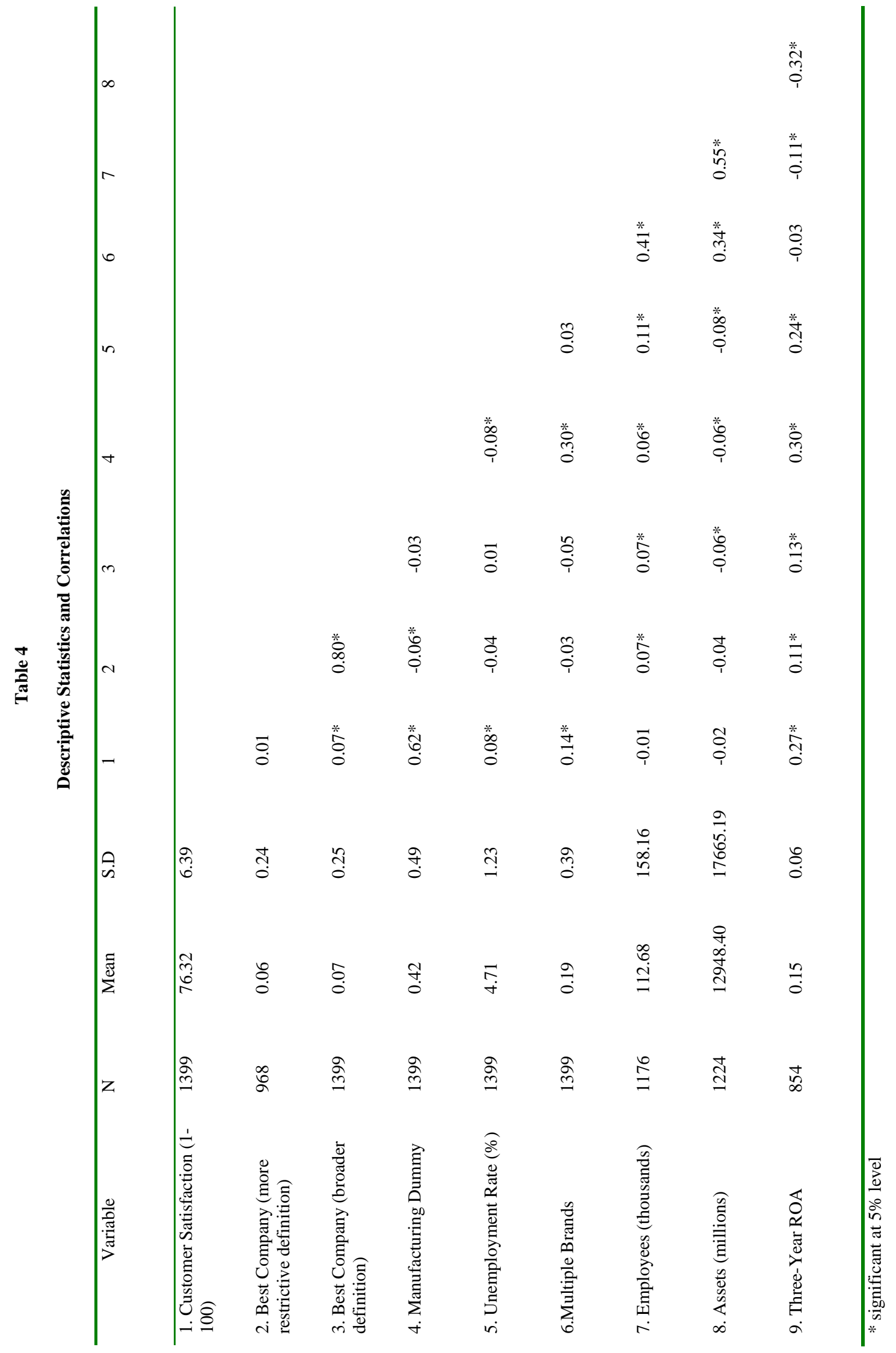


Table 5

Comparison of Means Between Included Best Companies \& All Other ACSI Firms

\begin{tabular}{|l|l|l|}
\hline & Included Best Companies & All Other ACSI Firms \\
\hline Assets (millions) & $\$ 7,470$ & $\$ 13,388^{* *}$ \\
\hline Employees (thousands) & 185 & $106^{* *}$ \\
\hline Unemployment Rate $(\%)$ & 4.73 & 4.70 \\
\hline Manufacturing Dummy & 0.36 & 0.42 \\
\hline Multiple Brands & 0.15 & 0.19 \\
\hline Three-Year ROA & 0.18 & $0.15^{* *}$ \\
\hline
\end{tabular}

** difference in means is statistically significant at one percent level on a two-tailed t-test 
Table 6

The Effect of Best Company Status on Customer Satisfaction Excluding Firm Fixed Effects (Hypothesis 1)

\begin{tabular}{|c|c|c|c|c|c|c|}
\hline & (1) & (2) & (3) & (4) & (5) & (6) \\
\hline Best Company (more restrictive definition) & $\begin{array}{l}3.006 \\
(0.699) * *\end{array}$ & $\begin{array}{l}2.910 \\
(0.692) * *\end{array}$ & $\begin{array}{l}2.312 \\
(0.725)^{* *}\end{array}$ & & & \\
\hline Best Company (broader definition) & & & & $\begin{array}{l}3.169 \\
(0.760)^{* *}\end{array}$ & $\begin{array}{l}2.963 \\
(0.736)^{* * *}\end{array}$ & $\begin{array}{l}2.767 \\
(0.761)^{* *}\end{array}$ \\
\hline Unemployment Rate & $\begin{array}{l}0.226 \\
(0.205)\end{array}$ & $\begin{array}{l}0.218 \\
(0.247)\end{array}$ & $\begin{array}{l}0.405 \\
(0.266)\end{array}$ & $\begin{array}{l}0.211 \\
(0.191)\end{array}$ & $\begin{array}{l}0.154 \\
(0.238)\end{array}$ & $\begin{array}{l}0.306 \\
(0.259)\end{array}$ \\
\hline Multiple Brands & $\begin{array}{l}0.113 \\
(0.557)\end{array}$ & $\begin{array}{l}0.241 \\
(0.709)\end{array}$ & $\begin{array}{l}0.676 \\
(0.742)\end{array}$ & $\begin{array}{l}-0.034 \\
(0.567)\end{array}$ & $\begin{array}{l}-0.185 \\
(0.652)\end{array}$ & $\begin{array}{l}-0.032 \\
(0.687)\end{array}$ \\
\hline Employees $^{\mathrm{a}}$ & & $\begin{array}{l}-0.281 \\
(0.270)\end{array}$ & $\begin{array}{l}0.203 \\
(0.294)\end{array}$ & & $\begin{array}{l}-0.202 \\
(0.285)\end{array}$ & $\begin{array}{l}0.308 \\
(0.293)\end{array}$ \\
\hline Assets $^{\mathrm{a}}$ & & $\begin{array}{l}-0.090 \\
(0.418)\end{array}$ & $\begin{array}{l}-0.789 \\
(0.317)^{*}\end{array}$ & & $\begin{array}{l}-0.099 \\
(0.399)\end{array}$ & $\begin{array}{l}-0.818 \\
(0.312)^{* *}\end{array}$ \\
\hline Past Three-Year ROA & & & $\begin{array}{l}13.051 \\
(4.556)^{* * *}\end{array}$ & & & $\begin{array}{l}8.933 \\
(3.977)^{*}\end{array}$ \\
\hline Constant & $\begin{array}{l}82.143 \\
(1.130)^{* *}\end{array}$ & $\begin{array}{l}79.607 \\
(2.424)^{* *}\end{array}$ & $\begin{array}{l}77.901 \\
(3.503)^{* *}\end{array}$ & $\begin{array}{l}68.297 \\
(1.359)^{* *}\end{array}$ & $\begin{array}{l}70.396 \\
(3.200)^{* *}\end{array}$ & $\begin{array}{l}72.351 \\
(2.853)^{* *}\end{array}$ \\
\hline Includes industry and quarter fixed effects & Yes & Yes & Yes & Yes & Yes & Yes \\
\hline Observations & 968 & 777 & 565 & 1399 & 1155 & 801 \\
\hline R-squared & 0.71 & 0.73 & 0.78 & 0.71 & 0.73 & 0.77 \\
\hline
\end{tabular}

+ significant at $10 \%$ level; $*$ significant at $5 \%$ level; ** significant at $1 \%$ level. One-tailed tests are the criteria for statistical significance of "Best Company", given that H1 is directional. Robust standard errors clustered on the parent company are in parentheses below each estimate.

${ }^{\mathrm{a}}$ Logarithm. 
Table 7

The Effect of Best Company Status on Customer Satisfaction Including Firm Fixed Effects (Hypothesis 1)

\begin{tabular}{|c|c|c|c|c|c|c|}
\hline & $(1)$ & (2) & (3) & (4) & $(5)$ & $(6)$ \\
\hline Best Company (more restrictive definition) & $\begin{array}{l}-0.247 \\
(0.381)\end{array}$ & $\begin{array}{l}-0.256 \\
(0.468)\end{array}$ & $\begin{array}{l}-0.213 \\
(0.437)\end{array}$ & & & \\
\hline Best Company (broader definition) & & & & $\begin{array}{l}0.899 \\
(0.499) * *\end{array}$ & $\begin{array}{l}0.929 \\
(0.495)^{* *}\end{array}$ & $\begin{array}{l}0.929 \\
(0.514) * *\end{array}$ \\
\hline Unemployment Rate & $\begin{array}{l}0.149 \\
(0.174)\end{array}$ & $\begin{array}{l}0.019 \\
(0.219)\end{array}$ & $\begin{array}{l}0.271 \\
(0.234)\end{array}$ & $\begin{array}{l}0.144 \\
(0.185)\end{array}$ & $\begin{array}{l}-0.052 \\
(0.228)\end{array}$ & $\begin{array}{l}0.263 \\
(0.227)\end{array}$ \\
\hline Multiple Brands & $\begin{array}{l}0.065 \\
(1.681)\end{array}$ & $\begin{array}{l}0.755 \\
(1.807)\end{array}$ & $\begin{array}{l}0.758 \\
(1.358)\end{array}$ & $\begin{array}{l}-0.731 \\
(1.080)\end{array}$ & $\begin{array}{l}-0.348 \\
(1.034)\end{array}$ & $\begin{array}{l}-0.208 \\
(0.873)\end{array}$ \\
\hline Employees $^{\mathrm{a}}$ & & $\begin{array}{l}-0.017 \\
(0.243)\end{array}$ & $\begin{array}{l}0.354 \\
(0.291)\end{array}$ & & $\begin{array}{l}-0.150 \\
(0.239)\end{array}$ & $\begin{array}{l}0.141 \\
(0.232)\end{array}$ \\
\hline Assets $^{\mathrm{a}}$ & & $\begin{array}{l}-0.575 \\
(0.878)\end{array}$ & $\begin{array}{l}-0.587 \\
(1.010)\end{array}$ & & $\begin{array}{l}-0.460 \\
(0.566)\end{array}$ & $\begin{array}{l}-0.254 \\
(0.652)\end{array}$ \\
\hline Past Three-Year ROA & & & $\begin{array}{l}16.173 \\
(7.325)^{*}\end{array}$ & & & $\begin{array}{l}6.552 \\
(5.739)\end{array}$ \\
\hline Constant & $\begin{array}{l}81.370 \\
(1.216)^{* *}\end{array}$ & $\begin{array}{l}86.535 \\
(7.147)^{* *}\end{array}$ & $\begin{array}{l}80.912 \\
(8.482)^{* *}\end{array}$ & $\begin{array}{l}77.276 \\
(1.157)^{* *}\end{array}$ & $\begin{array}{l}83.518 \\
(4.452)^{* *}\end{array}$ & $\begin{array}{l}79.341 \\
(5.370)^{* *}\end{array}$ \\
\hline Includes firm, industry, and quarter fixed effects & Yes & Yes & Yes & Yes & Yes & Yes \\
\hline Observations & 968 & 777 & 565 & 1399 & 1155 & 801 \\
\hline R-squared & 0.89 & 0.90 & 0.91 & 0.88 & 0.89 & 0.90 \\
\hline
\end{tabular}

+ significant at $10 \%$ level; * significant at 5\% level; ** significant at $1 \%$ level. One-tailed tests are the criteria for statistical significance of "Best Company", given that $\mathrm{H} 1$ is directional. Robust standard errors clustered on the parent company are in parentheses below each estimate. All models include firm, industry, and quarter fixed effects.

${ }^{a}$ Logarithm. 
Table 8

Comparing the Effect of Best Company Status on Manufacturing and Service Brands (Hypothesis 2)

\begin{tabular}{|c|c|c|c|c|c|c|}
\hline & (1) & (2) & (3) & (4) & $(5)$ & (6) \\
\hline $\begin{array}{l}\text { Best Company (Broader } \\
\text { definition) }\end{array}$ & $\begin{array}{l}4.608 \\
(0.875)^{* *}\end{array}$ & $\begin{array}{l}4.520 \\
(0.806) * *\end{array}$ & $\begin{array}{l}4.228 \\
(0.762) * *\end{array}$ & $\begin{array}{l}1.305 \\
(0.784)^{* *}\end{array}$ & $\begin{array}{l}1.754 \\
(0.800)^{* *}\end{array}$ & $\begin{array}{l}1.646 \\
(0.835)^{* *}\end{array}$ \\
\hline $\begin{array}{l}\text { Best Company } \times \text { Manufacturing } \\
\text { Dummy }\end{array}$ & $\begin{array}{l}-3.801 \\
(1.177)^{* *}\end{array}$ & $\begin{array}{l}-4.016 \\
(1.074) * *\end{array}$ & $\begin{array}{l}-3.951 \\
(1.132)^{* *}\end{array}$ & $\begin{array}{l}-0.764 \\
(0.990)\end{array}$ & $\begin{array}{l}-1.578 \\
(0.969)\end{array}$ & $\begin{array}{l}-1.482 \\
(0.966)\end{array}$ \\
\hline Unemployment Rate & $\begin{array}{l}0.154 \\
(0.181)\end{array}$ & $\begin{array}{l}0.049 \\
(0.212)\end{array}$ & $\begin{array}{l}0.178 \\
(0.226)\end{array}$ & $\begin{array}{l}0.139 \\
(0.184)\end{array}$ & $\begin{array}{l}-0.079 \\
(0.222)\end{array}$ & $\begin{array}{l}0.232 \\
(0.217)\end{array}$ \\
\hline Multiple Brands & $\begin{array}{l}-0.114 \\
(0.579)\end{array}$ & $\begin{array}{l}-0.332 \\
(0.667)\end{array}$ & $\begin{array}{l}-0.225 \\
(0.707)\end{array}$ & $\begin{array}{l}-0.728 \\
(1.080)\end{array}$ & $\begin{array}{l}-0.334 \\
(1.028)\end{array}$ & $\begin{array}{l}-0.192 \\
(0.880)\end{array}$ \\
\hline Employees $^{\mathrm{a}}$ & & $\begin{array}{l}-0.220 \\
(0.263)\end{array}$ & $\begin{array}{l}0.322 \\
(0.275)\end{array}$ & & $\begin{array}{l}-0.140 \\
(0.238)\end{array}$ & $\begin{array}{l}0.165 \\
(0.232)\end{array}$ \\
\hline Assets $^{\mathrm{a}}$ & & $\begin{array}{l}-0.063 \\
(0.386)\end{array}$ & $\begin{array}{l}-0.764 \\
(0.302)^{*}\end{array}$ & & $\begin{array}{l}-0.531 \\
(0.569)\end{array}$ & $\begin{array}{l}-0.339 \\
(0.648)\end{array}$ \\
\hline Past Three-Year ROA & & & $\begin{array}{l}10.268 \\
(4.122)^{*}\end{array}$ & & & $\begin{array}{l}6.693 \\
(5.717)\end{array}$ \\
\hline Constant & $\begin{array}{l}68.318 \\
(1.293)^{* *}\end{array}$ & $\begin{array}{l}70.341 \\
(3.089) * *\end{array}$ & $\begin{array}{l}71.989 \\
(2.715)^{* *}\end{array}$ & $\begin{array}{l}77.306 \\
(1.153)^{* *}\end{array}$ & $\begin{array}{l}84.529 \\
(4.458)^{* *}\end{array}$ & $\begin{array}{l}80.156 \\
(5.331)^{* *}\end{array}$ \\
\hline $\begin{array}{l}\text { Includes industry and quarter } \\
\text { fixed effects }\end{array}$ & Yes & Yes & Yes & Yes & Yes & Yes \\
\hline Includes firm fixed effects & No & No & No & Yes & Yes & Yes \\
\hline Observations & 1399 & 1155 & 801 & 1399 & 1155 & 801 \\
\hline R-squared & 0.71 & 0.73 & 0.78 & 0.88 & 0.89 & 0.90 \\
\hline
\end{tabular}

+ significant at $10 \%$ level; * significant at $5 \%$ level; ** significant at $1 \%$ level. One-tailed tests are the criteria for statistical significance of "Best Company" and its interaction with the Manufacturing dummy, given that both $\mathrm{H} 1$ and $\mathrm{H} 2$ are directional. Robust standard errors clustered on the parent company are in parentheses below each estimate.

${ }^{\mathrm{a}}$ Logarithm. 


\section{Table 9}

The Effect of Customer Satisfaction on Profitability

\begin{tabular}{|c|c|c|}
\hline & $\begin{array}{l}\text { (1) } \\
\text { Three-year ROA }\end{array}$ & $\begin{array}{l}\text { (2) } \\
\text { Three-year ROA }\end{array}$ \\
\hline Customer Satisfaction & $\begin{array}{l}0.003 \\
(0.001)^{* *}\end{array}$ & $\begin{array}{l}0.002 \\
(0.001)^{* *}\end{array}$ \\
\hline Unemployment Rate & $\begin{array}{l}0.013 \\
(0.007)+\end{array}$ & $\begin{array}{l}0.007 \\
(0.006)\end{array}$ \\
\hline \multicolumn{3}{|l|}{ Multiple Brands } \\
\hline Employees $^{\mathrm{a}}$ & $\begin{array}{l}-0.011 \\
(0.005) * *\end{array}$ & $\begin{array}{l}0.016 \\
(0.007)^{* *}\end{array}$ \\
\hline Assets $^{\mathrm{a}}$ & $\begin{array}{l}0.010 \\
(0.007)\end{array}$ & $\begin{array}{l}-0.015 \\
(0.007)^{* *}\end{array}$ \\
\hline Past Three-Year ROA & $\begin{array}{l}0.516 \\
(0.082)^{* *}\end{array}$ & $\begin{array}{l}-0.179 \\
(0.083)^{* *}\end{array}$ \\
\hline Constant & $\begin{array}{l}-0.208 \\
(0.083)^{* *}\end{array}$ & $\begin{array}{l}0.077 \\
(0.080)\end{array}$ \\
\hline Includes industry and quarter fixed effects & Yes & Yes \\
\hline Includes firm fixed effects & No & Yes \\
\hline Observations & 472 & 472 \\
\hline R-squared & 0.78 & 0.93 \\
\hline
\end{tabular}

+ significant at $10 \%$ level; * significant at $5 \%$ level; ** significant at $1 \%$ level. Robust standard errors clustered on the parent company are in parentheses below each estimate.

${ }^{\mathrm{a}}$ Logarithm. 